\title{
Potential of solid phase formation from thermal water in the region of Velingrad
}

\author{
Mila Trayanoval, Radostina Atanassova ${ }^{1}$,Edith Haslinger ${ }^{2}$, Otmar Plank ${ }^{2}$, \\ Stefan Wyhlidal', Aleksey Benderev ${ }^{l}$ \\ ${ }^{1}$ Geological Institute, Bulgarian Academy of Sciences, Acad. G. Bonchev Str., Bl. 24, 1113 Sofia, Bulgaria; \\ e-mails:milat@geology.bas.bg; radi@geology.bas.bg; aleksey@geology.bas.bg. \\ ${ }^{2}$ Austrian Institute of Technology, Center for Energy, Konrad-Lorenz-Str. 24, 3430 Tulln, Austria; \\ email: edith.haslinger@ait.ac.at.
}

(Accepted in revised form: November 2017)

\begin{abstract}
The Velingrad geothermal field is one of the largest in Bulgaria. Its water is widely used for balneology, spa tourism, sports, heating and other purposes. An interesting problem related with the operation of thermal water is the process of scaling or corrosion of equipment when the water passes through it. Specifically, for the geothermal field, a saturation index is used to assess whether the water is saturated or unsaturated, with regard to the respective mineral phase. The obtained results for this coefficient are compared with those for the existing water sources from the geothermal field and, depending on the location, temperature and other physicochemical differences, their variation is analyzed.
\end{abstract}

Trayanova, M., Atanassova, R., Haslinger, E., Plank, O., Wyhlidal, S., Benderev, A. 2017. Potential of solid phase formation from thermal water in the region of Velingrad. Geologica Balcanica 46 (2), 135-141.

Keywords: thermal water, saturation index, scaling, Velingrad geothermal field.

\section{INTRODUCTION}

The localities of thermal water in the region of Velingrad are one of the largest in Bulgaria and have great importance for treatment, prophylactics, rehabilitation, recreation, communal use, as well as for heating of buildings and facilities. Prolonged exploitation will result in undesirable processes related to dissolution and deposition of substances in the catchments, pipes and other equipment related to the utilization of heat.

The purpose of this study is to determine the potential of precipitation of mineral phases according to the specific hydrogeological and hydrochemical conditions of the water sources in the region. It is also interesting to establish the regularities in spatial changes of the saturation index values related to the factors affecting the chemical composition of the geothermal water sources.

\section{HYDROGEOLOGICAL SETTING}

The Velingrad geothermal field is located in the Rhodope massif, in the Chepinska River valley, one of the right tributaries of the Maritsa River. Its waters have been used since ancient times. Initially, there were a number of natural springs with temperature up to $77^{\circ} \mathrm{C}$ (e.g., Georgiev, 1904; Batakliev, 1930). Later on, since 1958, drilling studies have tapped water with higher temperatures to reach the current state of the geothermal field (e.g., Limonadov, 1964; Petrov, 1964; Petrov et al., 1970; Shterev, 1964; Hristov, 2001). Thermo-mineral waters are formed in the Chepinska Valley. It is a graben structure filled with non-consolidated Neogene and Quaternary sediments, formed within granitoids and high-grade metamorphic rocks of the Rhodopes, including marbles (Dimitrova and Katskov, 1990, Kozhoukharov et al., 1990). The natural drainage areas of the upstream waters, formed mainly in the granites, are attached to intersecting fracture disturbances (Fig. 1). More than 30 manifestations were found in four drainage zones, with different quantitative and qualitative parameters, located in different districts of Velingrad (Table 1). According to unpublished data of Stoyanov and Hristov, with increasing the temperature of the water from south to north, $\mathrm{pH}$ decreases (Fig. 2) and TDS increases, and 


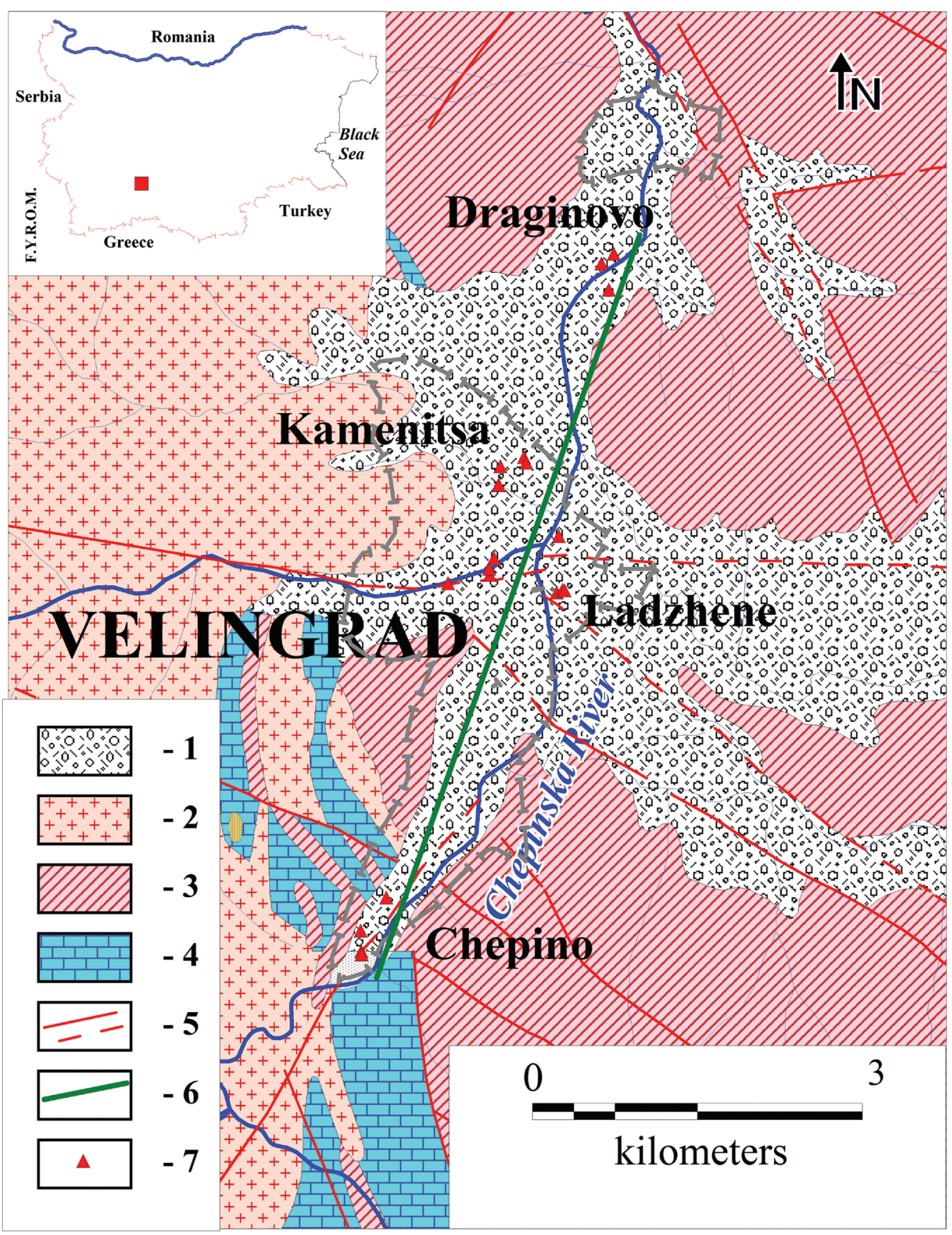

Fig. 1. Location and geological map of the studied area (after Dimitrova and Katskov, 1990; Kozhoukharov et al., 1992): 1-alluvial deposits; 2 - granites; 3 - gneisses, granites, slates and amphibolites; 4 - marbles; 5 - faults; 6 - profile line ChepinoDraginovo; 7 - tested thermal water sources (after Pentcheva et al., 1997).

Table 1

Characteristics of the groups of water sources in the region of Velingrad (after Petrov, 1997; Pentcheva et al., 1997

\begin{tabular}{|c|c|c|c|c|c|c|c|}
\hline \multirow{2}{*}{$\begin{array}{l}\text { Group of water } \\
\text { sources }\end{array}$} & \multicolumn{2}{|c|}{ Number of water sources } & \multirow{2}{*}{$\begin{array}{l}\text { Discharge of } \\
\text { groundwater } \\
\text { flow, } 1 / \mathrm{s}\end{array}$} & \multicolumn{2}{|c|}{ Temperature, ${ }^{\circ} \mathrm{C}$} & \multicolumn{2}{|c|}{$\mathrm{TDS}, \mathrm{mg} / \mathrm{l}$} \\
\hline & Boreholes & Springs & & $\min$ & $\max$ & $\min$ & $\max$ \\
\hline Chepino & 3 & 5 & 63 & 37 & 47 & 0.202 & 0.215 \\
\hline Ladzhene & 10 & 5 & 32.5 & 27 & 61.5 & 0.245 & 0.572 \\
\hline Kamenitsa & 2 & 3 & 24.2 & 59 & 89 & 0.607 & 0.764 \\
\hline Draginovo & 2 & 4 & $>12.3$ & 50 & 95 & 0.673 & 0.722 \\
\hline
\end{tabular}




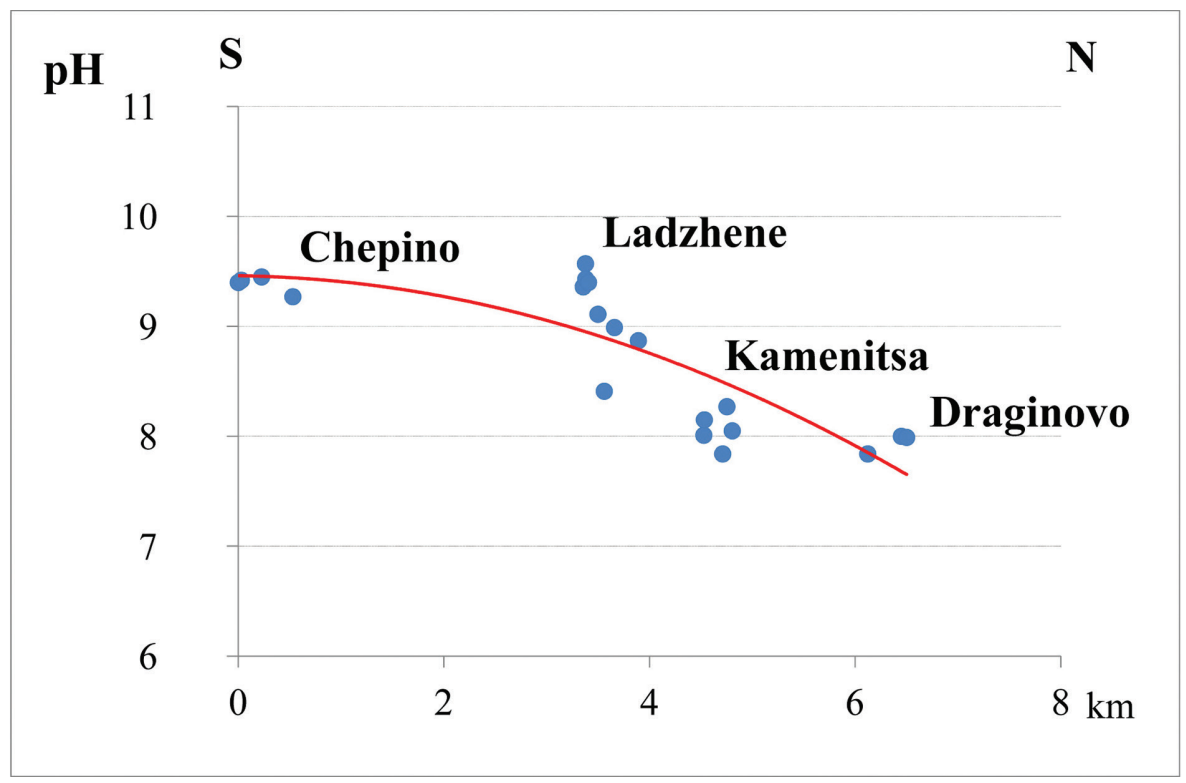

Fig. 2. Changing of $\mathrm{pH}$, from south to north, in profile line Chepino-Draginovo.

the type of water and the contents of some components change as well (Fig. 3).

\section{MATERIAL AND METHODS}

The important processes that hamper the operation of thermal water are substance deposition and corrosion of pipes and equipment. For their estimation and evaluation, a number of methodologies based on the treatment of hydrochemical data have been developed and applied. Most of them are focused on the deposition of carbonate and silicate materials (e.g., Boycheva, 2007; Rafferty, 1999; Zhang et al., 2001; Brown, 2011). The most commonly used indices are the Langelier Saturation Index (LSI) and the Ryznar Stability Index (RSI), introduced by Carrier (1965). Both are mainly focused on processes related to the $\mathrm{CaCO}_{3}$ system:

$$
\begin{gathered}
\mathrm{LSI}=\mathrm{pH}-\mathrm{pH}_{\mathrm{s}} \\
\mathrm{RSI}=2 \mathrm{pH}_{\mathrm{s}}-\mathrm{pH},
\end{gathered}
$$

where: $\mathrm{pH}_{\mathrm{s}}$ is the $\mathrm{pH}$ value of water when it is fully saturated with $\mathrm{CaCO}_{3}$. It is estimated by the following formula:

$$
\mathrm{pH}_{\mathrm{s}}=(9,3+\mathrm{A}+\mathrm{B})-(\mathrm{C}+\mathrm{D}),
$$

where:

$$
\mathrm{A}=\frac{(\log (\mathrm{TDS})-1)}{10}
$$

$$
\begin{gathered}
\mathrm{B}=\left(-13.12 \log \left(\mathrm{T}^{\circ} \mathrm{C}+273\right)\right)+34.55 ; \\
\mathrm{C}=(\log (\text { calcium hardness }))-0.4 ; \\
\mathrm{D}=\log (\text { alkalinity }) .
\end{gathered}
$$

In the thermal waters studied, other mineral phases that can precipitate are presented. The estimation of the potential of deposition or dissolution of the corresponding phase is performed, using the so-called Saturation Index (SI). According to Garrels and Christ (1965), SI represents the decimal logarithm of the product of the activities of the ions raised to the respective stoichiometric ratios to the solubility product of the respective mineral phase. It can be determined by various software products, such as VISUAL MINTEQ 3.1 , which is a freeware chemical equilibrium model maintained by Jon Petter Gustafsson at KTH Royal Institute of Technology, Stockholm (Sweden). This software allows a relatively fast processing of many input data: basic physicochemical parameters (temperature, $\mathrm{pH}$, redox potential) and the contents of various ions and elements in the aqueous solution. The main outputs are the indices of saturation of a large number of mineral phases and forms of the elements in the water.

The composition of the thermal water in the Velingrad geothermal field was studied by Azmanov (1940), Kusitaseva and Melamed (1957), Pencheva (1960), Petrov and Pencheva (1962), Shterev and Hristov (1985), Pentcheva et al., (1997), Stoyanov and Hristov (unpublished data) and others. In the present study, data and analyses from Pentcheva et al. (1997) were used. Temperature, electrical conductivity, oxidation-reduction potential, alkalinity and gas content in 25 water basins were measured in-situ. Twenty of them are among the most important natural and artificial geothermal water fields and five are of cold-water springs. Chemical analyses were performed in the laboratory of the University of Antwerp (Belgium). Some of the interpretations and 


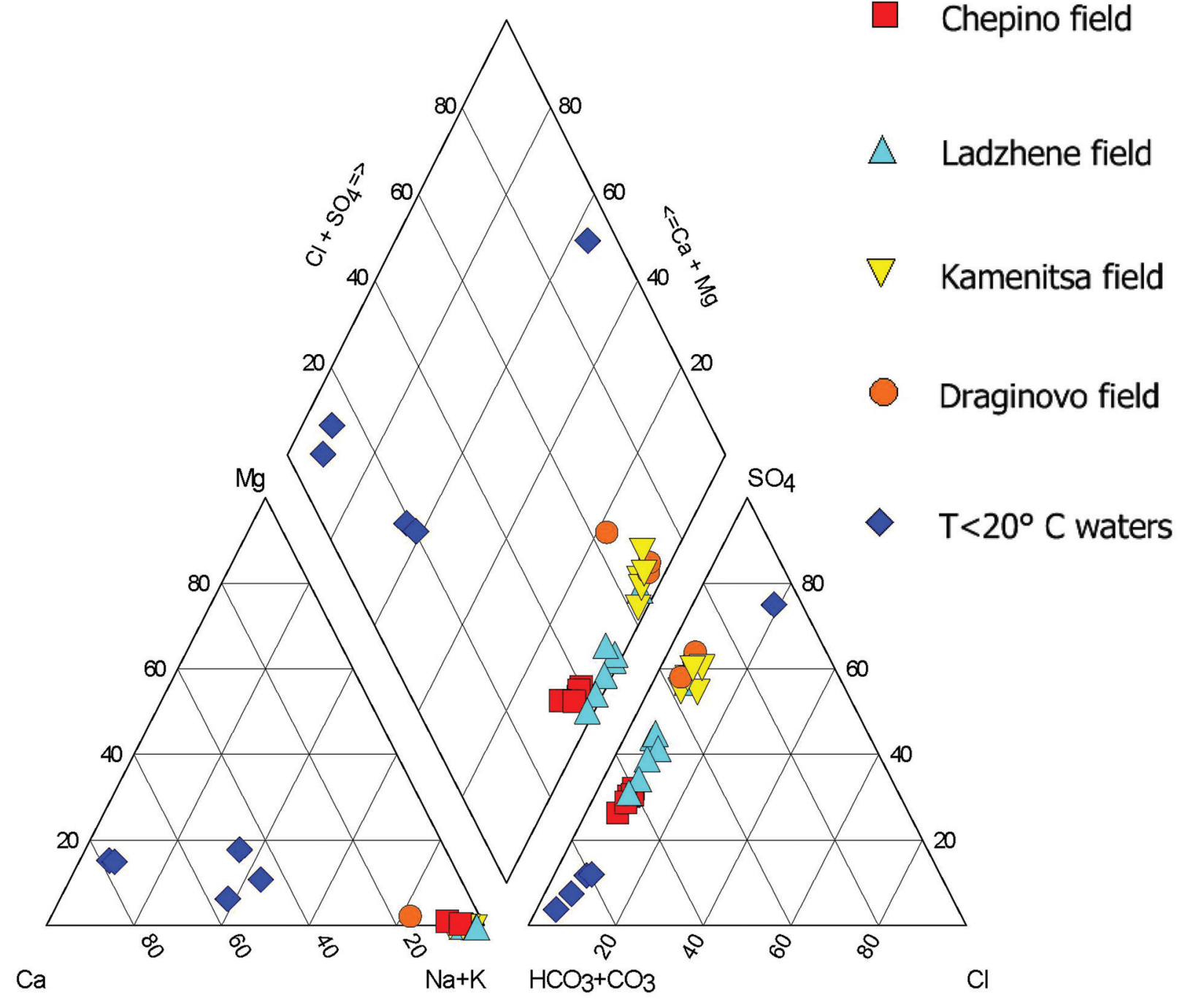

Fig. 3. Groundwater types of the thermal water in the region of Velingrad.

conclusions given in unpublished data by of Stoyanov and Hristov were also used.

\section{RESULTS AND DISCUSUONS}

Calculations of the Langelier Saturation Index (LSI) and the Ryznar Stability Index (RSI) (Fig. 4) point that, according to LSI, the thermal waters have values close to 0.5 , characterized as "slightly scaleforming and corrosive" (Fig. 4a). According to RSI, there is a much better differentiation of the thermal waters in the four zones (Fig. 4 b). The water sources from Chepino and Ladzhene, where the temperatures are lower and the $\mathrm{pH}$ values higher, are defined as "heavy corrosion". Only two of the water sources at Ladzhene, which have the lowest $\mathrm{pH}$ values compared to the others, fall in the category "corrosion significant". The water sources at Kamenitsa and Draginovo, which have a higher temperature and a lower $\mathrm{pH}$, are characterized by "little scale or corrosion".

To estimate the potential of deposition of different mineral phases (over 180), the values of the respective saturation indices were calculated, using the VISUAL MINTEQ 3.1 software and its database. Although the database used by this software and other similar software are applicable to waters with relatively low temperatures, the results provide a good idea of the probability of precipitation or dissolving mineral phases. It has been established that in one, several or all water sources the water is saturated (i.e., SI $>0$ for some mineral phases). The saturation index for 19 mineral phases has a positive value only in one of each water source. Water from all tested sites is saturated with quartz, 19 with $\mathrm{FCO}_{3}$-apatite and 14 with calcite and 


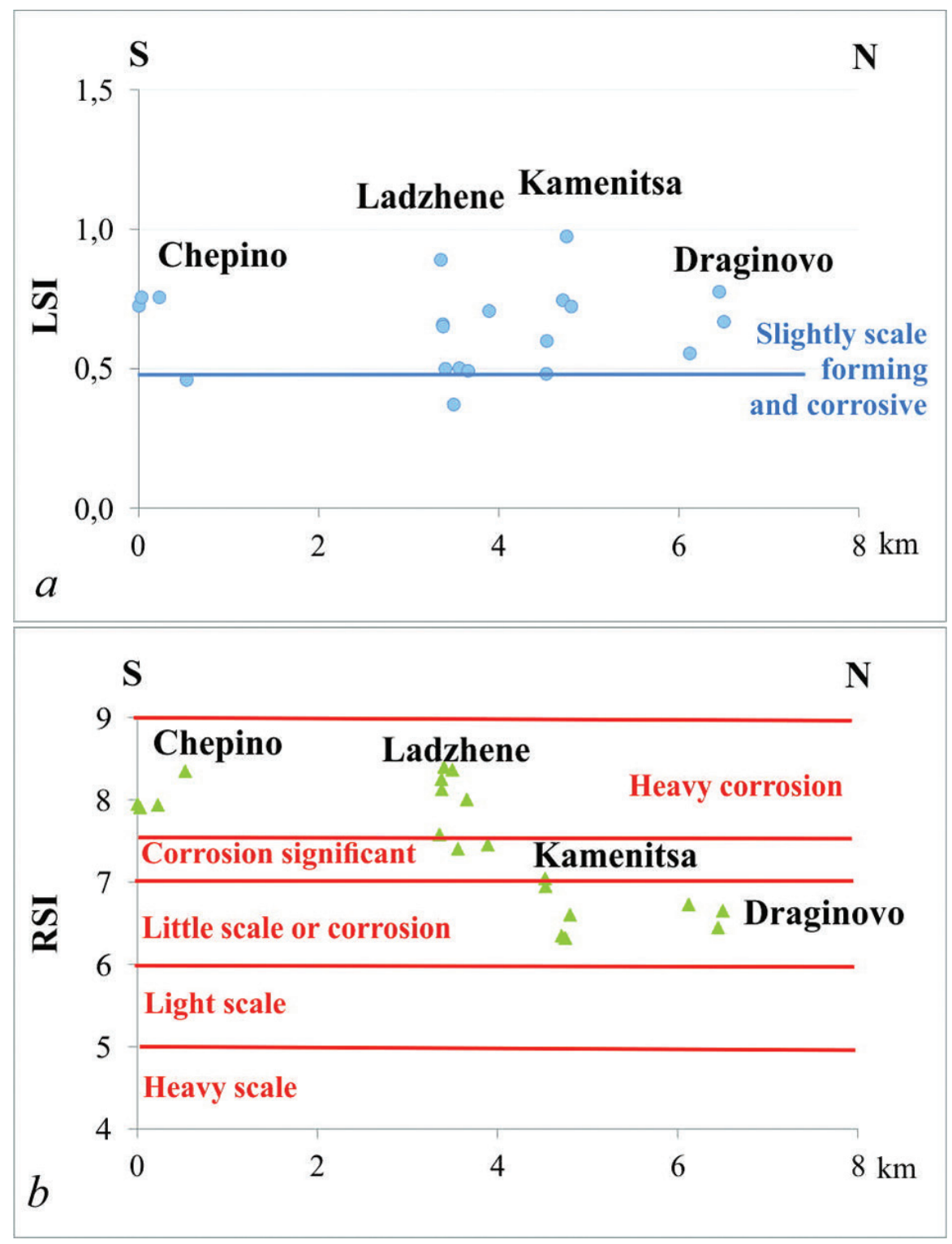

Fig. 4. Values and definitions of LSI $(a)$ and RSI (b) (according to Carrier Air Conditioning Company Handbook, 1965) of thermal waters in Velingrad region.

hydroxyapatite. More often, the water is saturated with chalcedony, in eight water sources. It is noteworthy that the mineral phases involving rare and dispersed elements cannot be deposited in substantial amounts, despite the saturation, due to their low concentrations. Of an interest is the spatial distribution of saturated and unsaturated waters with respect to $\mathrm{CaCO}_{3}, \mathrm{SiO}_{2}$ and apatite varieties, which can be deposited in more significant quantities (Fig. $5 a-c$ ).

$\mathrm{FCO}_{3}$-apatite, whose saturation indices vary from 1.7 to 16 (Fig. 5), has the highest potential of deposition. There is a downward trend in the index from south to north, with the exception of some higher values of water sources in the Ladzhene area, within the $\mathrm{E}-\mathrm{W}$ oriented fault zone. The saturation index regarding to $\mathrm{FCO}_{3}$-apatite of mixed thermal water with shallow cold water in the Draginovo area is exceptionally high. Similar spatial regularity is also observed for the hydroxyapatite index, but its values are lower in the Kamenitsa and Draginovo regions, where the water is close to equilibrium or slightly undersaturated. Regarding the mineral phases of $\mathrm{SiO}_{2}$ (quartz and chalcedony), there is an inverse dependence: the saturation indices increase, albeit in a much smaller range from south to north, with an increase in water temperature. The water in all water sources is saturated with quartz and, regarding chalcedony, in most cases they are undersaturated or close to equi- 


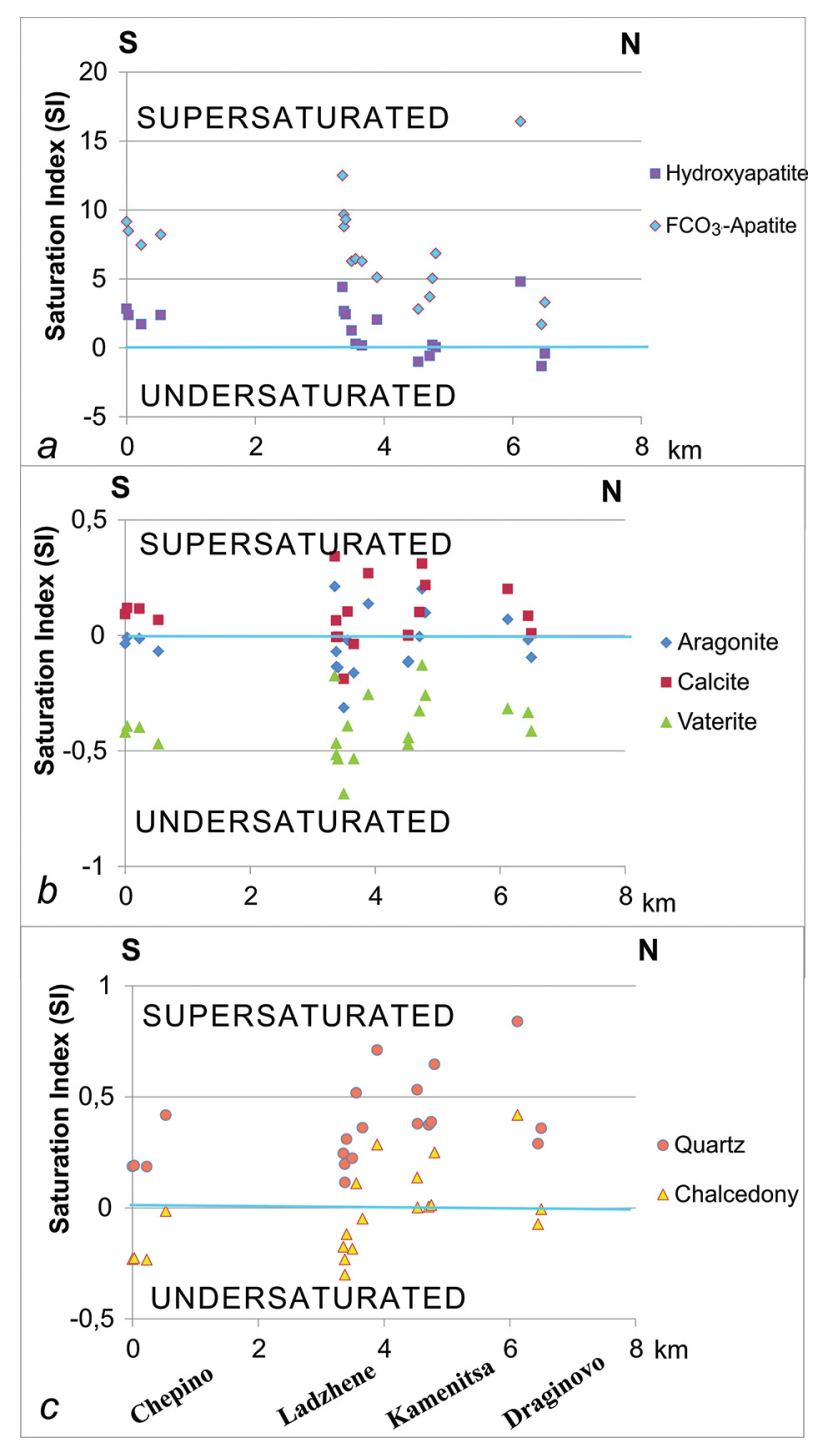

Fig. 5. Saturation indices of apatite forms by zones $(a), \mathrm{SiO}_{2}(b)$ and $\mathrm{CaCO}_{3}(c)$. librium, except for several water sources in the region of Ladzhene, Kamenitsa and Draginovo. In terms of $\mathrm{CaCO}_{3}$ forms, thermal waters are characterized by a relatively small variation of its saturation index, from 1 to 0.5 (i.e., the waters are close to equilibrium). Calcite, and to a lesser extent aragonite, has the highest potential to be deposited. Saturation indices for vaterite are negative.

\section{CONCLUSIONS}

The obtained results allow establishing the influence of thermal waters on the water facilities in the region of one of the largest geothermal fields in Bulgaria: Velingrad. Primarily, attention was paid to the precipitation potential of mineral phases from the thermal waters in the region. The most serious risk for such processes, under the existing physicochemical conditions, is related to some phosphate minerals, $\mathrm{SiO}_{2}$ and $\mathrm{CaCO}_{3}$ varieties. Some conditions may favor deposition of particular mineral phases containing rare and distracted elements (e.g., Sn, V, U, Pd and La). The results are a base for a future studies on changes in physicochemical conditions, such as temperature, pressure, gas composition, etc., in places where thermal water can be found in surficial wells.

\section{Acknowledgements}

The research was carried out in the framework of the bilateral cooperation project between Bulgaria and Austria NTCO 1-8 "Scaling and corrosion in hydrogeothermal plants and wells in Austria and Bulgaria - a comparison", financed by the Austrian Federal Ministry of Science, Research and Economy (BMWFW) and by the Bulgarian Ministry of Education and Science (Scientific Research Fund).

\section{REFERENCES}

Azmanov, A. 1940. Bulgarian mineral springs. Darzhavna Pechatnitsa, Sofia, $256 \mathrm{pp}$. (in Bulgarian).

Batakliev, I. 1930. Chepino (special geographical studies). Annuaire de l'Université de Sofia 25 (1), 119 pp. (in Bulgarian).

Boycheva, S. 2007. Evaluation of scale formation and corrosion potential in geothermal heating systems. The Energy forum, Varna, Bulgaria, 8 pp. (http://www.iaea.org/inis/ collection/NCLCollectionStore/_Public/39/043/39043273. pdf) (in Bulgarian).

Brown, K. 2011. Thermodynamics and kinetics of silica scaling. Proceedings of the International Workshop on Mineral Scaling, Manila, Philippines, 1-8.
Carrier Air Conditioning Company. 1965. Handbook of Air Conditioning System Design. McGraw-Hill Books, New York, $786 \mathrm{pp}$.

Dimitrova, R., Katskov, N. 1990. Explanatory note for the geological map of Bulgaria in scale 1:100 000, Velingrad map sheet. Committee on Geology, Company for Geophysical surveys and Geological mapping, Sofia, 52 pp. (in Bulgarian, with English abstract).

Garrels, R., Christ, L. 1965. Solution, minerals and equilibria. Harper and Row, New York, $450 \mathrm{pp}$.

Georgiev, V. 1904. The mineral baths in Bulgaria and their healing action. "Sveta Sofia" Publishing House, Sofia, 108 pp. (in Bulgarian). 
Hristov, V. 2001. Use of chemical geothermometry and heliometry in the study of hydrothermal deposits and thermal conducting structures in southern Bulgaria. PhD thesis, Geological Institute of the Bulgarian Academy of Sciences, Sofia, 187 pp. (in Bulgarian; unpublished).

Kozhoukharov, D., Dimitrova, R., Katskov, N. 1992. Explanatory note for the geological map of Bulgaria in scale 1:100 000, Pazardzhik map sheet. Committee on Geology, Company for Geophysical surveys and Geological mapping, Sofia, 54 pp. (in Bulgarian, with English abstract).

Kusitaseva, B., Melamed, J. 1958. Composition of the Bulgarian Mineral Waters. Chemical composition studies. Meditsina i fizkultura, Sofia, $278 \mathrm{pp}$. (in Bulgarian).

Limonadov, K. 1964. Hydrogeological study of thermal mineral springs in the Velingrad valley. Hydrotechnics and meliorations 3, 90-91 (in Bulgarian).

Pencheva, E. 1960. Spectrographic studies on the microcomponents of the mineral waters in the Chepinska River valley. Bulletin of the Geological Institute 8, 193-201 (in Bulgarian).

Petrov, P. 1964. The warm mineral waters in the Chepino valley. Travaux sur la géologie de Bulgarie, Série 3, 159-185 (in Bulgarian).

Pentcheva, E., Van't dack, L., Veldeman, E., Hristov, V., Gijbels, R. 1997. Hydrogeochemical characteristics of geo- thermal systems in South Bulgaria. University of Antwerpen, $121 \mathrm{pp}$.

Petrov, P. 1997. Hydrothermal resources in the Chepinska Valley. Report on the Project "Re-estimation of geothermal energy resources in Bulgaria". Geological Institute of the Bulgarian Academy of Sciences, Sofia, 17 pp. (in Bulgarian).

Petrov, P., Pencheva, E. 1962. On the hydrogeochemistry of rare and scattered elements in Bulgarian mineral waters. Bulletin of the Geological Institute 10, 267-301 (in Bulgarian).

Petrov, P., Martinov, S., Limonadov, K., Straka, Y. 1970. Hydrogeological studies of mineral waters in Bulgaria. Tehnika, Sofia, 195 pp. (in Bulgarian).

Rafferty, K. 1999. Scaling in geothermal heat pump systems. A report prepared for the U.S. Department of Energy, Contract No. DE-FG07-90ID 13040. Geo-Heat Center, Oregon Institute of Technology, $63 \mathrm{pp}$.

Shterev, K. 1964. Mineral waters in Bulgaria. Nauka i izkustvo, Sofia, 172 pp. (in Bulgarian).

Shterev, K., Hristov, V. 1985. Investigation of helium in thermal water in the Velingrad field. Proceedings of the $X X I^{s t}$ International Congress "SITH”, 66-76 (in Russian).

Zhang, Y., Shaw, H., Farquhar, R., Dawe, R. 2001. The kinetics of carbonate scaling-application for the prediction of downhole carbonate scaling. Journal of Petroleum Science and Engineering 29 (2), 85-95. 